\title{
Review \\ Mechanical Properties and Microstructure of Shotcrete under High Temperature
}

\author{
Guoming Liu ${ }^{1,2}$, Jipeng Zhao ${ }^{3, *}$, Zhixue Zhang ${ }^{4}$, Chenglong Wang ${ }^{1, *}$ and Qianqian $\mathrm{Xu}^{1, *}$ \\ 1 College of Safety and Environmental Engineering, Shandong University of Science and Technology, \\ Qingdao 266590, China; skd995978@sdust.edu.cn \\ 2 State Key Laboratory of Mining Disaster Prevention and Control Co-Founded by Shandong Province and \\ Ministry of Science and Technology, Shandong University of Science and Technology, Qingdao 266590, China \\ 3 College of Energy and Mining Engineering, Shandong University of Science and Technology, \\ Qingdao 266590, China \\ 4 Ventilation and Dust Prevention Department of Feicheng Mining Group Co., Ltd., Tai'an 271600, China; \\ zxzhang@gsm.pku.edu.cn \\ * Correspondence: jipengzhao0429@163.com (J.Z.); wclcm@sdust.edu.cn (C.W.); 13864240150@163.com (Q.X.)
}

check for updates

Citation: Liu, G.; Zhao, J.; Zhang, Z.; Wang, C.; Xu, Q. Mechanical

Properties and Microstructure of Shotcrete under High Temperature. Appl. Sci. 2021, 11, 9043. https:// doi.org/10.3390/app11199043

Academic Editors: Carlos Thomas and Doo-Yeol Yoo

Received: 30 June 2021

Accepted: 14 September 2021

Published: 28 September 2021

Publisher's Note: MDPI stays neutra with regard to jurisdictional claims in published maps and institutional affiliations.

Copyright: (c) 2021 by the authors. Licensee MDPI, Basel, Switzerland. This article is an open access article distributed under the terms and conditions of the Creative Commons Attribution (CC BY) license (https:/ / creativecommons.org/licenses/by/ $4.0 /)$.

\begin{abstract}
High temperature is recognized as one of the extreme environments in the application of shotcrete which significantly deteriorate the performance of shotcrete. This paper reviews the mechanical properties and microstructure of shotcrete under high temperature. First of all, this paper reviews the cause of formation of high ground temperature. Based on these causes, the author establishes a heat transfer model with a spiral shape by introducing a multidimensional morphological formula into the heat conduction process. Then, the paper reviews the influence of high temperature on the mechanical and micro properties of shotcrete, the cooling technology under high temperature, and the optimization research technology of shotcrete. The author discusses the influence of high temperature on the thermal parameters and the deformation of shotcrete from the perspective of thermodynamics. Multiple studies have shown that the irregular movement and disorderly overlapping of molecules in the shotcrete caused by the high temperature environment result in the premature termination of the hydration reaction of cement in shotcrete. Finally, the author suggests the challenges of high-temperature shotcrete in term of the process structure, performance optimization, and application in special engineering fields. The research in this paper intends to give guidance to those conducting shotcrete research under high temperature, and to promote the further development of shotcrete technology.
\end{abstract}

Keywords: high temperature; shotcrete; mechanical properties; microscopic properties

\section{Introduction}

With the swift global development of tunnels, mines, subways, water conservancy and hydropower projects, and so on, shotcrete, as an advanced support method, is widely applied to surrounding rock control and roadway closure. Shotcrete is a kind of concrete formed by mixing concrete materials, such as gel material, aggregate, and so on, into the ejection equipment, by means of compressed air or other power transmission, and sprayed onto the spray surface at high speed [1]. Shotcrete technology was first used in mining and civil engineering by the United States in 1914. It has a history of more than 100 years. This method is used in underground and tunnel support, infrastructure repair and rehabilitation, slope stabilization, and in areas difficult to reach with conventional concrete, such as bridge piers and beam soffits [2]. Shotcrete has the characteristics of high compressive strength, good durability, and wide range of strength grades [3-5]. As a supporting material of roadway, shotcrete can not only prevent the oxidation of surrounding rock, but also plays a supporting role for the roadway. With the development of deep mines and deep tunnels, shotcrete is facing great challenges. Especially deep underground, high temperature 
accelerates the deterioration of shotcrete [6-9]. According to relevant reports, the rock wall temperature of Sangzhuling Tunnel in the Yarlung Zangbo River Canyon in China reached $89^{\circ} \mathrm{C}$, and it was identified as a class I risk tunnel. The high temperature of $75^{\circ} \mathrm{C}$ and the extreme temperature of $170{ }^{\circ} \mathrm{C}$ were encountered in the construction of Anfang tunnel and the third hydropower station of Heibu in Japan. The highest original rock temperature is $46.8^{\circ} \mathrm{C}$, at $-980 \mathrm{~m}$ level in Sanhejian coal mine. The underground rock temperature of the Mbonig gold mine in South Africa reaches $65.6^{\circ} \mathrm{C}$.

Many scholars have shown that there is a certain relationship between temperature and depth, and the rock temperature gradient is about $3-4{ }^{\circ} \mathrm{C} / 100 \mathrm{~m}$ [10-12]. However, in a deep environment, due to the different rock properties and the possible existence of large fault zones, the change of temperature with temperature gradient is not obvious. Figure 1 shows the distribution of temperature with depth in deep tunnels and deep mines in some projects. From the figure, it could be concluded that the variation between temperature and depth in underground projects was a nonlinear relationship, that is, the ground temperature in deep environments shows an abnormal pattern [13,14].

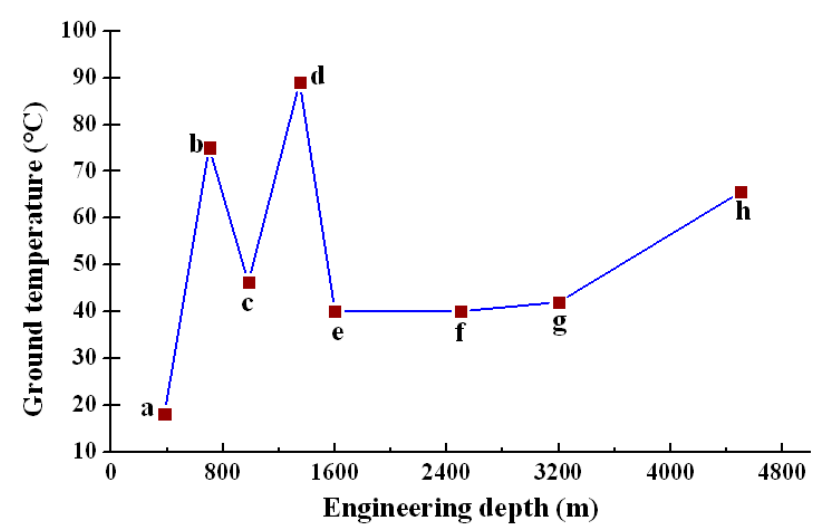

Figure 1. Temperature distribution of tunnels and mines with different depths.

In Figure 1: a-Albert tunnel in Austria; b-Anfang highway tunnel in Japan; cSanhejian coal mine in China; $\mathrm{d}$-Sangzhuling tunnel in China; e-Qinling tunnel of Xikang railway in China; $\mathrm{f}-$ Franco-Yibulangfeng highway tunnel; g-Kolar gold mine in India; $\mathrm{h}-$ Mponig gold mine in South Africa.

When shotcrete as support structure contacts with high-temperature rock wall, the performance of shotcrete may change. High temperature leads to the deterioration of shotcrete structure and the weakening of roadway stability. In recent years, many scholars have studied the mechanical properties and micro-morphology of shotcrete under high temperature. For example, Lee and Yang et al. $[15,16]$ studied the variation of shear properties of shotcrete with granite cementation surface roughness and temperature. The results showed that there were critical values for the effects of granite cementation surface roughness and temperature on shear strength. Moreover, the temperature was the most important factor affecting the shear performance of shotcrete. Wang et al. [17,18] studied the impermeability of shotcrete under standard working conditions and variable temperature conditions. The results showed that the temperature destroys the dense structure inside the shotcrete, resulting in an increase in the impermeability of the shotcrete. Wang and Cui et al. [19] studied the effect of temperature on the bond strength between shotcrete and rock surface, and found that the bond strength first increased and then decreased with the increase of temperature. Dong et al. [20] studied the fracture process of the interface between shotcrete and rock, and found that under high temperature, the structure of shotcrete fracture surface was loose and powder particles increased. Yang et al. [21] studied the internal damage mechanism of shotcrete under high temperature based on CT technology and X-ray, and the results showed that the internal pores of shotcrete present the trend of small holes gradually developing into large pores with the increase of temperature. 
Lu et al. [22,23] studied the residual properties of shotcrete after high temperature, and found that the main factors affecting the residual strength were curing conditions and cooling methods. Kjellsen et al. [24] studied the consolidation process of concrete in a thermal environment, and found that the compaction degree of the concrete decreased, and internal cracks occurred during the solidification process. Then, the microstructure of concrete was scanned by scanning electron microscopy (SEM), and it was found that the cracks developed along the interior of the aggregate. Akca et al. [25] studied the structural performance of high-performance shotcrete under high temperature, and concluded that the overall strength of shotcrete showed an upward trend under high temperature.

Although there are many studies on the performance changes of shotcrete under high temperature, there are few systematic reviews on the mechanical and micro properties of shotcrete. Therefore, this article systematically describes the development of mechanical properties and microstructure of shotcrete under high temperature. The research in this paper is intended to give guidance to those conducting shotcrete research under high temperature, and to promote the further development of shotcrete technology.

\section{Causes of High Ground Temperature and Its Influence on Shotcrete Structure}

In deep mines and deep tunnels, the phenomenon of high ground temperature is the biggest problem in the process of excavation and support. It will not only worsen the construction environment and reduce the labor production efficiency, but also change the shotcrete structure and affect the stability of the tunnel, thus threatening the safety of construction personnel. This chapter will discuss the cause of high ground temperature and the influence of high temperature on shotcrete structure.

\subsection{Causes of Formation of High Ground Temperature}

The earth's temperature is produced by the decay of radioactive elements in the earth's interior, and heat is accumulated in the earth's crust $[26,27]$. Then, heat is transmitted through rocks to the earth's surface. Because of the strong gravitational field inside the earth, there is a lot of energy in the inner core of the earth, and the temperature of the core is about $6000{ }^{\circ} \mathrm{C}$. However, most of the energy gradually disappears in the process of transmission. Because of the low thermal conductivity and poor heat transfer performance of rocks, heat energy builds easily in the rock mass, which makes the high temperature phenomenon appear in deep tunnels or mines; the remaining small part of energy will continue to transmit to the earth's surface [28-30]. Therefore, the main heat source for the formation of the earth's surface geothermal field is from the earth's interior. Although the transmission of energy is very small, the geothermal field formed in this process is still very harmful to human infrastructure work. In addition, the undulation and structural form of the base also have a certain influence on the formation temperature. When the tunnels and mines are deep in large fault zones, the temperature difference may reach $2-4{ }^{\circ} \mathrm{C} / 100 \mathrm{~m}$ [31]. This is a further challenge to the original high-temperature environment.

The heat of the earth's surface layer is from the earth's interior, and is transmitted to the shallow part of the earth's surface through heat conduction [32]. This mode of transmission is one-dimensional propagation. The temperature change can be expressed by one-dimensional conduction Equation (1):

$$
\frac{d^{2} \theta}{d z^{2}}=0
$$

In Equation (1): $\theta$-temperature; $Z$ —depth

However, in a deep environment, due to the complex geological environment, most of the strata are in a non-horizontal state. The transmission mode of temperature is diverse and controlled by many factors. At this time, the heat conduction occurs in a two dimensional or three dimensional shape. The one-dimensional conduction formula in the 
above Equation (1) cannot reflect the temperature propagation law at this time. Therefore, the following Equation (2) is introduced [33]:

$$
\frac{\partial}{\partial x}\left(\frac{\partial \theta}{\partial x}\right)+\frac{\partial}{\partial z}\left(\lambda \frac{\partial \theta}{\partial z}\right)+A=0
$$

In Equation (2): $\lambda$ 一thermal conductivity of rock; $A$-heat production of radioactive elements in rock.

The above Equation (2) shows that depth, rock thermal conductivity, and radioactive element heat production are the main factors affecting the temperature in deep environments. This is because the greater the depth, the greater the gravitational potential energy and the more heat generated. In a deep environment, the closer to the crust, the greater the influence of radioactive element decay heat production. However, rock is an anisotropic heterogeneous material, and its thermal conductivity is variable and generally decreases with the increase of temperature. Therefore, in a deep environment, due to the low thermal conductivity of rock, it shows strong heat storage capacity, resulting in a high-temperature environment.

Heat can be imagined as a fluid, and the fluid can be divided into steady-state type and non-stationary type in the process of transmission [34]. The heat transfer process is an unsteady state. Figure 2 shows the physical structure model of heat transfer. Luo et al. [35,36] analyzed the heat transfer phenomenon in the flow process, and results showed that heat flow is a process of energy exchange. Therefore, the author divides the heat transfer process into three types: linear, curved, and spiral. Due to the thermal conductivity of rock, the heat transferred from the deep to the ground is mainly linear [37,38]. In the process of tunnel construction, the heat is mainly curved and spiral; the heat flow transferred by curve will continue to diffuse around; the heat transferred in this form is not stored much in the rock. The heat transferred by spiral type will not disappear, but will accumulate continuously in the process of transmission, which will enhance the heat storage capacity of rock. At the same time, the spiral transmission is also the dominant part of deep high temperatures.

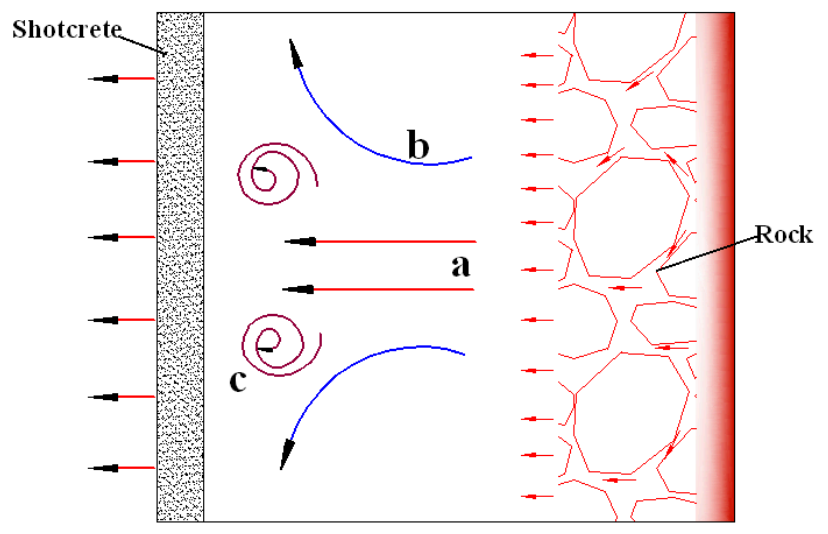

Figure 2. Heat transfer model: (a) linear type, (b) curve type, (c) spiral type.

\subsection{Influence of High Temperature on Shotcrete Structure}

In a deep construction environment, the heat flow transmission path in the stratum is cut off indirectly because of the tunnel excavation. As a result, the heat storage capacity of the roadway is strengthened. Combined with the impact pressure in the formation, it can easily cause structural instability and structural deformation of the roadway. On the one hand, the shotcrete layer may fall off seriously; on the other hand, it will affect the selection of construction materials and the durability of shotcrete $[39,40]$. Furthermore, the additional temperature stress can also cause the shotcrete lining to crack, which will have a great impact on the initial support of the roadway. For example, Zhu et al. [41] introduced a thermal crack mechanism and considered that shotcrete was a heterogeneous mixed 
material, and the thermodynamic properties of shotcrete aggregate and cement paste were not matched under the influence of temperature. As a result, radial and circumferential cracking will occur inside the shotcrete. The internal cracking of aggregate and cement paste will occur, resulting in the spalling of shotcrete surface, as shown in Figure 3.

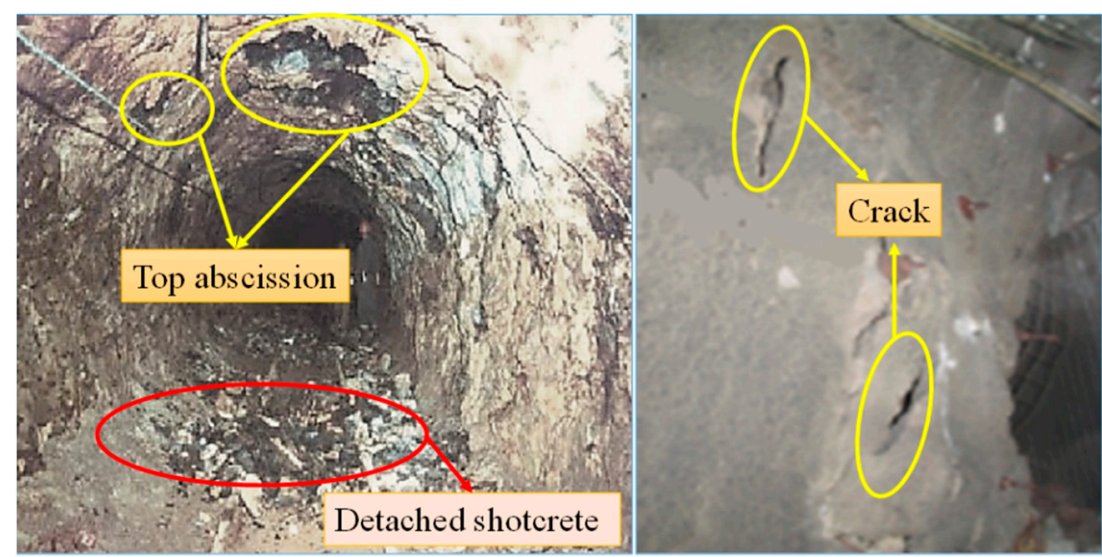

Figure 3. Shotcrete layer falling off at high temperature.

In order to further study the mechanism of cracks in roadway concrete under high temperature, we summarize the early cracking phenomenon of shotcrete. The lining shotcrete under a high-temperature heat-damaged roadway can easily deteriorate in the process of pouring and curing. One reason is that the high temperature makes the water in the fresh concrete evaporate rapidly, forming large voids or cracks; another reason is that when shotcrete adheres to high-temperature surrounding rock, it has high-temperature stress. In addition, high temperature changes the hydration products and progress of cement. These reasons are worthy of in-depth study. For example, Li et al. [42] studied the influence of temperature, water/cement ratio, and fly ash content on the early crack resistance of high-performance shotcrete, and results indicated that temperature was the primary factor affecting the early crack-resistance performance. Huang et al. [43] studied the performance of early-age concrete under fire and found that the residual compressive strength of concrete showed a downward trend with temperature. It was also found that the internal damage to concrete specimens was serious: the hydration products C-S-H gel and $\mathrm{Ca}(\mathrm{OH})_{2}$ crystals were basically decomposed, leading to an imbalance of concrete structure stability. Qin et al. [44] studied high-strength shotcrete at $80{ }^{\circ} \mathrm{C}$. They found that the early performance of shotcrete was significantly improved, and the frost resistance and chloride ion penetration resistance of shotcrete were improved. Some scholars have carried out X-ray diffraction (XRD) tests on shotcrete at different temperatures. The XRD spectra of shotcrete at $30{ }^{\circ} \mathrm{C}$ and $60{ }^{\circ} \mathrm{C}$ is shown in Figure 4; results show that the content of $\mathrm{CH}$ crystal at $60^{\circ} \mathrm{C}$ is higher than at $30^{\circ} \mathrm{C}$. This shows that the hydration degree of shotcrete cement is better at $60^{\circ} \mathrm{C}$, and more C-S-H gel is generated. Therefore, obtaining a certain temperature is conducive to the early strength development of shotcrete.

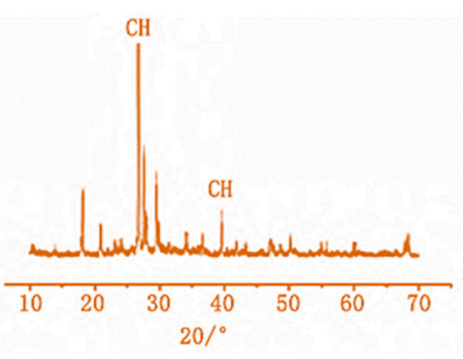

(a)

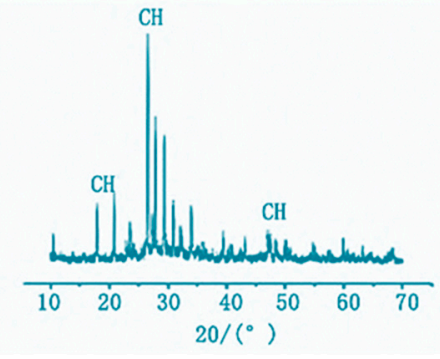

(b)

Figure 4. XRD patterns of shotcrete at different temperatures: (a) $30^{\circ} \mathrm{C}$, (b) $60{ }^{\circ} \mathrm{C}$ [45]. 
Hiremath et al. [46] studied the development of early strength of shotcrete under the conditions of hot water bath and hot air curing; they found that the early strength of shotcrete showed an upward trend with the increase of temperature and that hot water bath curing was conducive to the development of early strength of shotcrete. Wonsuk et al. [47] studied slag shotcrete and found that under high-temperature conditions, the output of $\mathrm{CO}_{2}$ in cement decreased and the early strength of shotcrete was significantly improved. The linear expansion value of slag shotcrete is very low and the pozzolanic activity is high, which is conducive to the development of shotcrete strength at the later stage [48]. As shown in Figure 5, D'Aloia et al. [49] carried out a numerical simulation on the cracking performance of tunnel lining shotcrete. The results showed that early creep has a good effect (Figure 5a). When the creep is ignored, the thermal damage occurs in a large range of shotcrete lining structure (Figure $5 \mathrm{~b}$ ). By comparing the simulation results of thermal shrinkage and autogenous shrinkage (Figure $5 \mathrm{c}$ ), it can be concluded that thermal shrinkage is the main cause of early transverse cracks. Therefore, in a high-temperature environment, the shrinkage phenomenon occurs in the roadway wall concrete under the influence of temperature, resulting in cracks in the shotcrete.

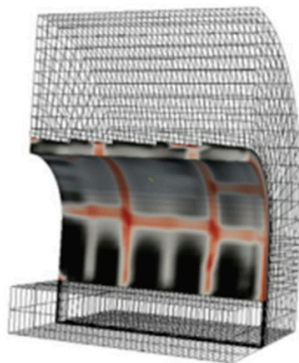

(a)

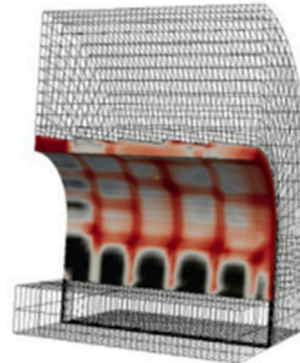

(b)

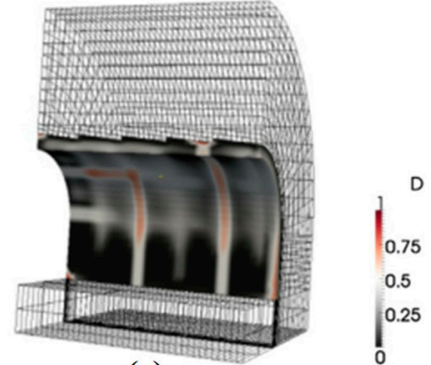

(c)

Figure 5. Damage field caused by different phenomena after $360 \mathrm{~h}$ (heat shrinkage and selfcontraction) [49]. (a) Creep is considered; (b) creep is ignored; and (c) only thermal shrinkage is considered.

\section{Mechanical Properties and Microstructure of Shotcrete under High Temperature}

Shotcrete technology is the preferred technology for roadway support at present. Under high temperature, however, the mechanical properties of shotcrete will be changed. This section discusses the performance of shotcrete under different factors under high temperature.

\subsection{Variation Law of Compressive and Flexural Strength of Shotcrete}

With the increasing number of high-temperature construction sites, some scholars have studied the influence of formation temperature on shotcrete, firstly through the change of compressive and flexural strength. As shown in Figure 6, Liu et al. [50] found that the compressive strength and splitting tensile strength of shotcrete increased with the increase of curing age through standard curing in a $40-100{ }^{\circ} \mathrm{C}$ dry and hot environment. Under a dry and hot environment of $60-100{ }^{\circ} \mathrm{C}$, it shows an increasing trend before curing for $7 \mathrm{~d}$, and has an obvious downward trend after $7 \mathrm{~d}$. After curing for $28 \mathrm{~d}$, the compressive strength under high temperature is lower than that under standard curing. At $7 \mathrm{~d}$ and $28 \mathrm{~d}$, the splitting tensile strength of concrete decreases with the increase of curing temperature. Similarly, Zhu et al. [51] found that the initial setting time and final setting time of highstrength shotcrete shortened with the increase of curing temperature, and analyzed the compressive strength of high-strength shotcrete with the curing ages of $3 \mathrm{~d}$ and $28 \mathrm{~d}$. The results showed that the overall compressive strength presents an increasing trend, but when the temperature is too high, the compressive strength of shotcrete has an obvious shrinkage phenomenon. 


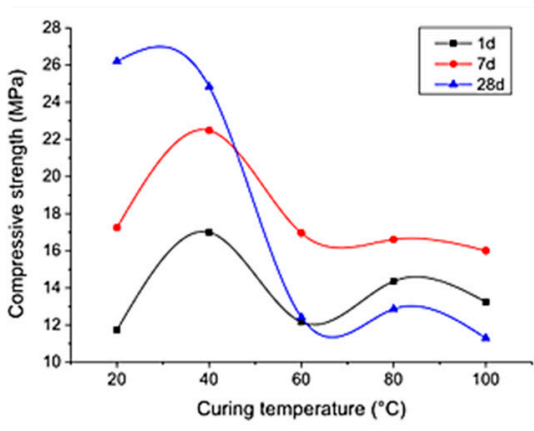

(a)

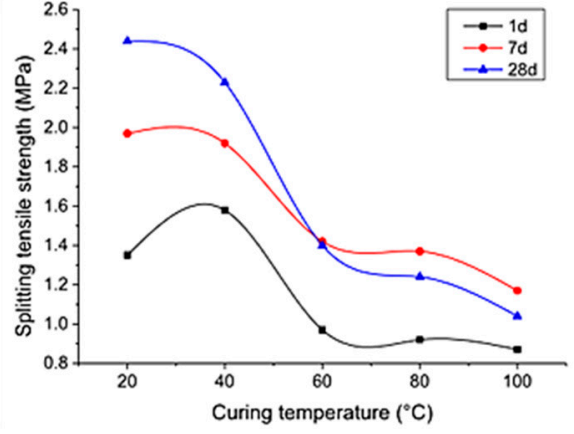

(b)

Figure 6. Mechanical properties of specimens under various working conditions: (a) compressive strength test, (b) splitting tensile strength test [50].

The above research only expounds the deterioration law of shotcrete as a macro phenomenon, but does not explain the causes of deterioration from the micro level.

In order to deeply study the influence of high temperature on the deterioration of shotcrete, scholars analyzed the deterioration mechanism of shotcrete from the perspectives of carbonation depth and early hydration products of cement.

In view of the critical size effect of concrete under high temperature, scholars have proposed using acoustic emission technology to evaluate the internal structural defects and damage of concrete [52-54]. Relevant conclusions show that there is a negative correlation between temperature and acoustic emission signal. Before the compressive strength of concrete has reached the critical point, the acoustic emission number and energy of concrete showed an increasing trend, until the concrete members were completely destroyed [55].

Li et al. [56] studied the carbonation degree of shotcrete under high temperature, and noted that the compressive strength of shotcrete decreased with the increase of temperature. Results showed that the carbonation depth of shotcrete at a high temperature of $50{ }^{\circ} \mathrm{C}$ was more than 4 times higher than that at a normal temperature, which easily reduced the alkalinity and damaged the sealing structure of the shotcrete. Xie et al. [57] found serious cracks on the surface of $100^{\circ} \mathrm{C}$ high-temperature shotcrete, and preliminarily explained the phenomenon of shrinkage of shotcrete compressive strength. The early hydration products formed too fast, resulting in disordered accumulation of products, which made the distribution uniformity of the shotcrete's internal structure worse. The later high temperature caused the hydration products to move strongly, and most of the hydration products deposited near the larger aggregate. Figure 7a shows the X-ray diffraction (XRD) patterns of shotcrete cured at $80^{\circ} \mathrm{C}$ for $3 \mathrm{~h}, 4 \mathrm{~h}, 5 \mathrm{~h}$, and standard curing. The AFt diffraction peak decreases and the C-S-H and $\mathrm{C}_{3} \mathrm{~S}$ diffraction peaks increase with the curing time at high temperature. This showed that short-term high-temperature curing could strengthen the compactness of shotcrete. Meanwhile, Wang et al. [58] also detected C-S-H phase at $0-60^{\circ} \mathrm{C}$, showing an increasing trend. In addition, many scholars have explained that the increase of shotcrete compactness was due to the gradual loss of shotcrete crystal water in the gradually increasing temperature gradient, and a large amount of ettringite (Aft) would be transformed into monosulfide calcium sulphoaluminate (Afm) $[53,59]$. 

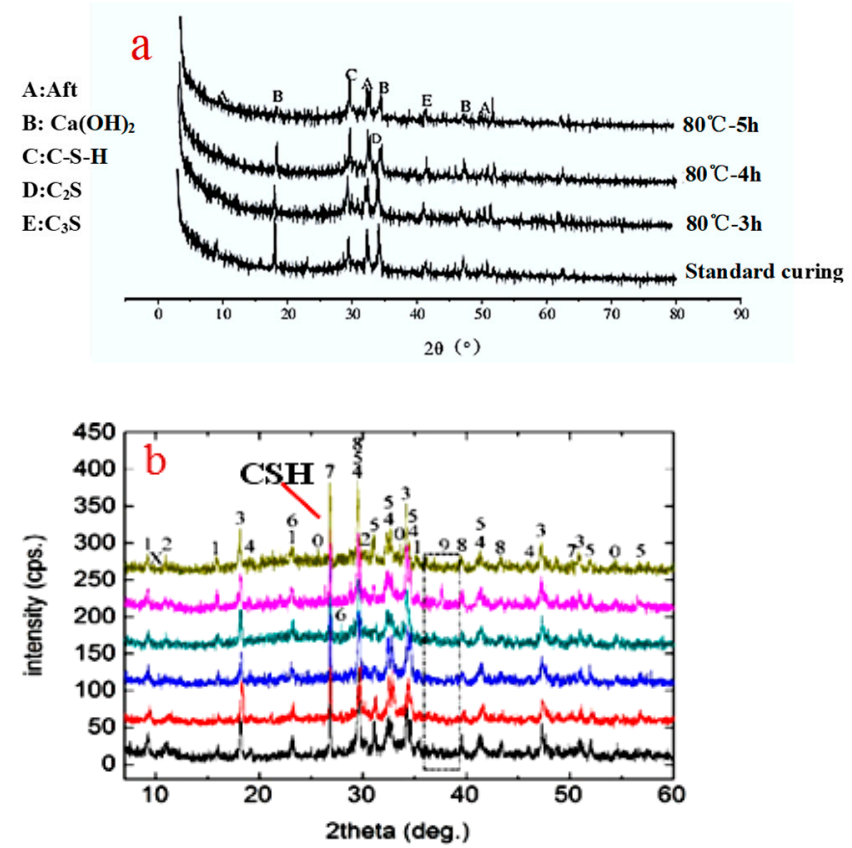

Figure 7. XRD spectra of different curing systems: (a) different curing time (b) Different curing temperatures $[57,58]$.

Calvo et al. [60] carried out microscopic analysis of shotcrete at $90{ }^{\circ} \mathrm{C}$ temperature, and found that the rate of C/S in C-S-H gel increased slightly after thermal curing, while the ratio of $(\mathrm{A}+\mathrm{F}) / \mathrm{C}$ and Sulphates/C decreased, indicating that the properties of C-S-H gel changed under high temperature (mainly sulfate content), as shown in Table 1.

Table 1. Chemical composition of C-S-H gel formed in concrete under different conditions [60].

\begin{tabular}{ccccc}
\hline \multirow{2}{*}{ Curing } & \multirow{2}{*}{ Concrete Type } & \multicolumn{3}{c}{ C-S-H gels Composition } \\
\cline { 3 - 5 } & & C/S & A + F/C & Sulphates/C \\
\hline \multirow{2}{*}{ Standard } & H & $1.68 \pm 0.06$ & $0.145 \pm 0.033$ & $0.104 \pm 0.048$ \\
& F & $1.84 \pm 0.29$ & $0.159 \pm 0.057$ & $0.061 \pm 0.021$ \\
\hline \multirow{2}{*}{ Heat curing } & H & $1.84 \pm 0.12$ & $0.124 \pm 0.026$ & $0.074 \pm 0.011$ \\
& F & $2.04 \pm 0.35$ & $0.093 \pm 0.004$ & $0.057 \pm 0.015$ \\
\hline
\end{tabular}

H: Cement content 100\%; F: $20 \%$ limestone instead of $20 \%$ cement.

A group of scholars have studied the performance of shotcrete under ultra-high temperatures (the temperatures were higher than $150{ }^{\circ} \mathrm{C}$ ), and found that the compressive strength and flexural strength of shotcrete continue to decline with the increase of temperature, and that the damage to shotcrete's internal structure caused by ultra-high temperatures is very serious [61-63]. Under ultra-high temperatures, calcium hydroxide and wollastonite in shotcrete decompose to generate a large amount of calcium oxide, which leads to the instability of the shotcrete's internal structure. Wang et al. [64] studied the influence of temperature and humidity on shotcrete, and found that low-temperature and high-humidity curing conditions were conducive to the development of shotcrete strength at later stages.

The above research lacks studies on the micro void structure of shotcrete. As we all know, the change of micro void structure affects the mechanical properties of shotcrete. With the development of new detection technology, scholars use SEM, CT, and the mercury intrusion method (MIP) to measure the change of voids in shotcrete, so as to further explain the influence mechanism of high temperature on concrete deterioration.

Furthermore, scholars have studied the microstructure of shotcrete under high temperature. Figure 8 show SEM images of ceramsite shotcrete at different temperatures. At $20^{\circ} \mathrm{C}$, 
the shotcrete presents a particle aggregation state, and the structure is stable. At $40{ }^{\circ} \mathrm{C}$, the shotcrete structure is gradually destroyed, and the particles are granular in structure. At a temperature of $60{ }^{\circ} \mathrm{C}$, the concrete particles are small, there are a lot of micro pores, the structure is loose, and the degree of hydration is low, which leads to a decrease in shotcrete strength. The reason is that ceramsite is a microporous medium, and with the increase of temperature, it accelerates the water evaporation of shotcrete, so the hydration structure of the shotcrete is relatively dispersed.
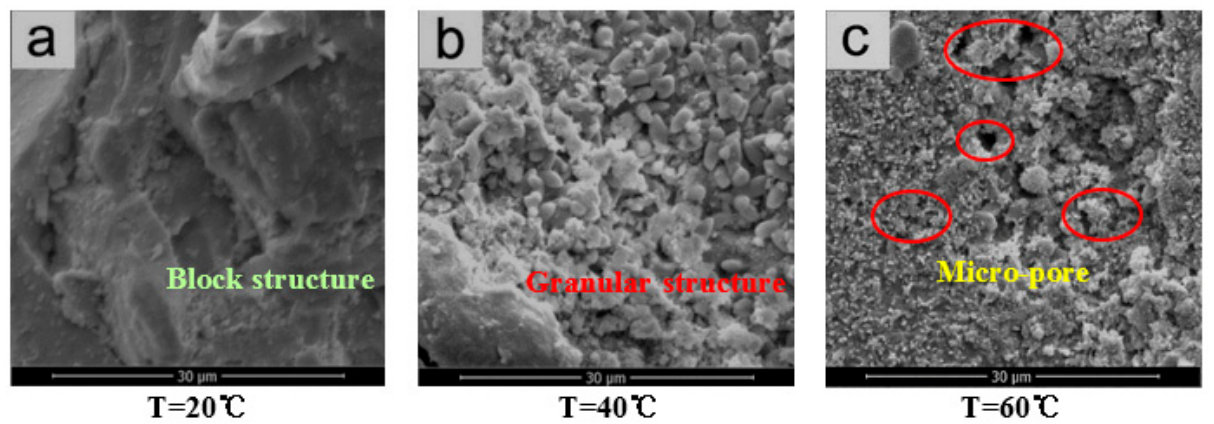

Figure 8. SEM photos of ceramsite concrete curing at different temperatures [65].

Chen and Wei et al. [66,67] found that there was a correlation between the fractal dimension of pore volume and the strength by establishing the fractal model; that is, the more pores there are and the larger they are, the lower the strength of the shotcrete. Some studies have also shown that the permeability of shotcrete could be improved by increasing the integral dimensions of the pores [68]. Illhami et al. [69] studied the performance of shotcrete under high temperature, and concluded that there was an obvious correlation between ultrasonic pulse velocity and compressive strength, that is, the use of ultrasonic pulse velocity method was a feasible method to estimate the high-temperature compressive strength of shotcrete cover. Yang et al. [70] explained that in a hot and humid environment, the expansion stress in AFt caused by too high of a temperature led to structural damage and weakening of the mechanical properties of shotcrete. Shen et al. [71] used the mercury intrusion method (MIP) to study the change of shotcrete porosity at different temperatures, and concluded that the porosity of shotcrete had a strong correlation with the compressive strength; that is, the higher the porosity of shotcrete, the lower the compressive strength. This was expressed by Schiller [72]:

$$
\sigma=\operatorname{Dln}\left(\frac{\sigma_{0}}{P}\right)
$$

where $\sigma$ is the compressive strength of concrete, $P$ is the porosity, $\sigma_{0}$ is the ideal compressive strength when the porosity is 0 , and $\mathrm{D}$ is the empirical constant.

At present, in terms of the mechanical properties of shotcrete, scholars have studied the impact of low to ultra-high temperatures on concrete. The span of temperature basically covers the range of environmental changes on site. Scholars have not only studied the macro cracks, but also deeply analyzed the deterioration mechanism of shotcrete from the perspective of the micro void structure. However, the correlation between the macro phenomenon and the microstructure of shotcrete in a high-temperature environment is little understood. It is necessary to further strengthen the relationship between the two, especially the macro and micro relationship model, so as to better provide a theoretical basis for research on shotcrete in high-temperature environments.

\subsection{Bond Strength between Shotcrete and Coal (Rock) Interface}

The bond between shotcrete and coal (rock) interface has been a key problem in roadway support. It was necessary to further study the mechanical properties of the interface under high temperature [73,74]. As shown in Figure 9, Ma et al. [75] studied the 
relationship between surrounding rock and shotcrete cohesion based on a high-groundtemperature simulation experiment. By setting the temperature range at $50-90^{\circ} \mathrm{C}$, the bond strength decreases with the increase of rock wall temperature. At the same time, when the temperature exceeds the critical value, the bond performance of shotcrete will shrink. In addition, CT scanning was performed on the surface of shotcrete at $50{ }^{\circ} \mathrm{C}$ and $90{ }^{\circ} \mathrm{C}$. It was observed that the surface deterioration of shotcrete at $90^{\circ} \mathrm{C}$ was more serious than that at $50^{\circ} \mathrm{C}$, with a large number of pores, as shown in Figure 10.

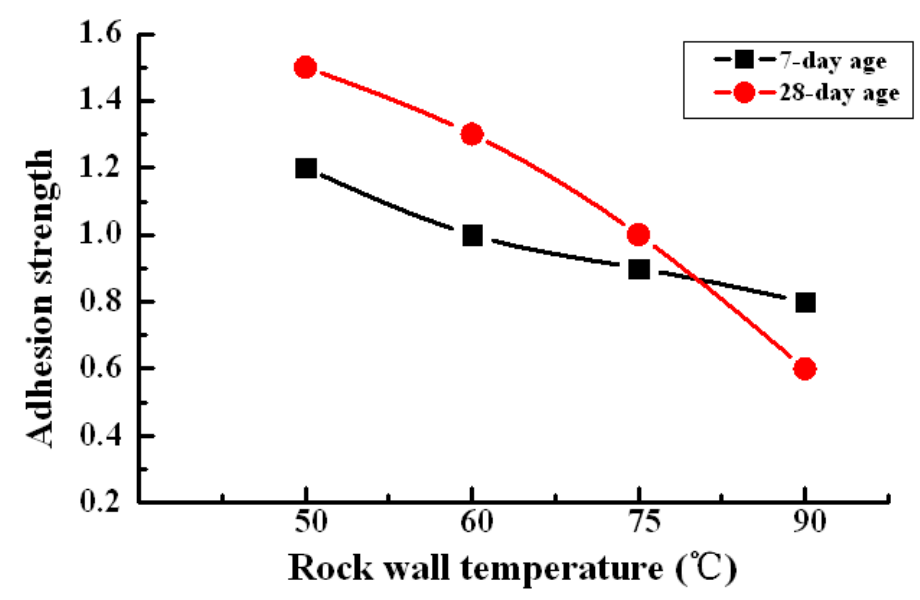

Figure 9. Data of bond strength between surrounding rock and shotcrete under different working conditions [75].

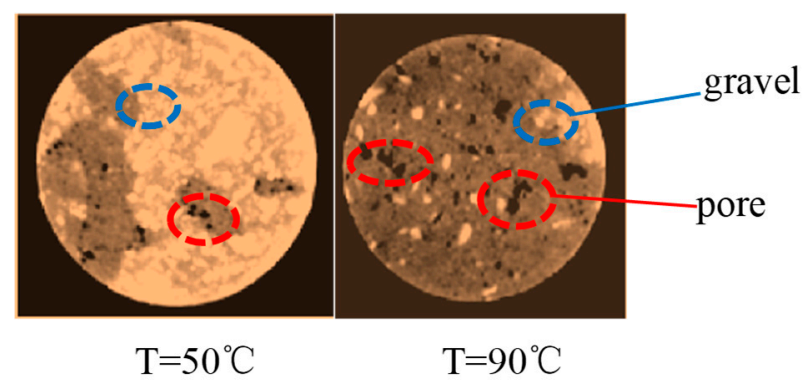

Figure 10. CT scan image of bonding surface [75].

Yang et al. [16] studied the bond strength of shotcrete under $70^{\circ} \mathrm{C}$ working conditions in a hot and humid environment, and concluded that a dry and hot environment had the greatest impact on the performance of shotcrete, and would accelerate the retrogradation of shotcrete [19,76]. Su et al. [77-79] carried out finite element analysis on the temperature field of shotcrete rock slab, and found that temperature determined the damage degree of bond strength between shotcrete and rock slab. The heat and the moisture in shotcrete were mainly lost and evaporated through the side wall of the specimen. As shown in Figure 11, the internal pores of shotcrete under various temperature conditions was analyzed. It was determined that the pore area is proportional to the development of the temperature. For one thing, the high temperature led to a rapid evaporation of water in the shotcrete, and pores formed during the hydration process of the cement; for another, the impact force generated in the process of shotcrete spraying caused the shotcrete to be mixed with air, thus producing bubbles, resulting in an increase in the number of pores in shotcrete under high temperature. 


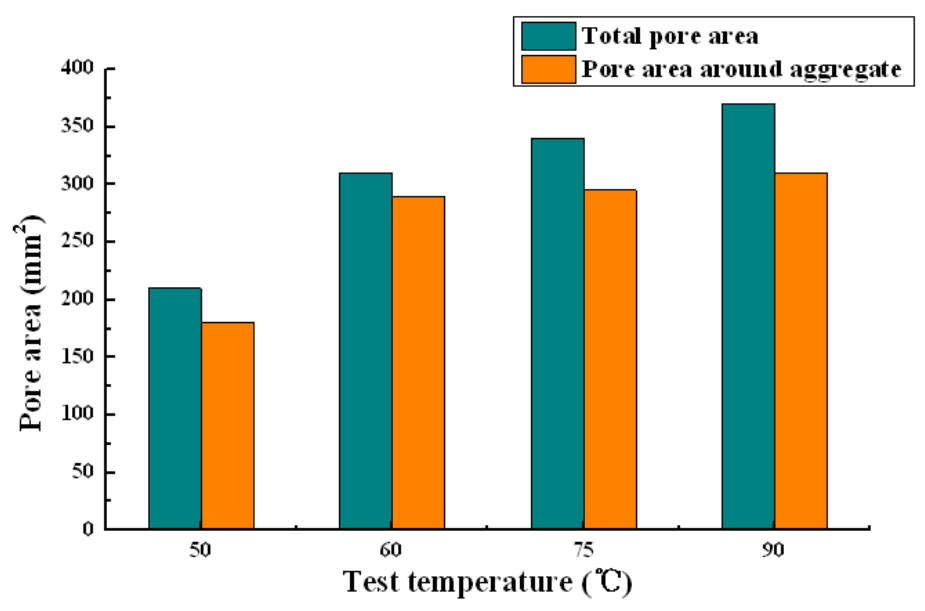

Figure 11. Comparison of total pore and surrounding pore of aggregate at each temperature [79].

Fan et al. [80] studied the bond strength of shotcrete under high temperature by the. splitting method and drawing method, as shown in Figure 12. Because the splitting failure was accompanied by shear phenomenon, the bond strength of shotcrete measured by splitting method was better than that by drawing method under high temperature. It was also found that the cracks on the cemented surface of concrete due to autogenous shrinkage at a high temperature of $60^{\circ} \mathrm{C}$ and thermal decomposition still occurred in the transition zone between shotcrete and rock. Duan et al. [81] pointed out in the paper that relevant scholars believe that $75^{\circ} \mathrm{C}$ is the critical temperature for thermal damage of shotcrete, and beyond this temperature, shotcrete will lose its adhesion.

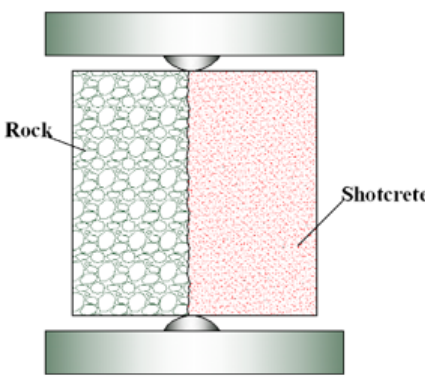

(a)

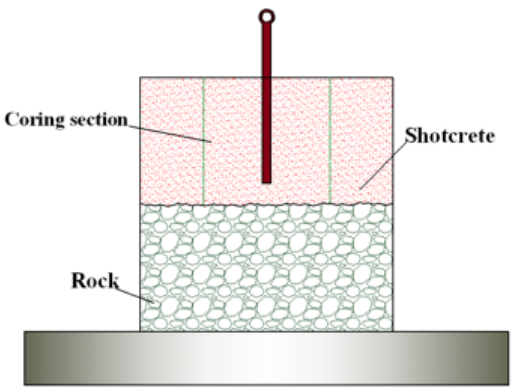

(b)

Figure 12. Schematic diagram of bond strength test: (a) splitting method and (b) core drilling and drawing method.

Tang et al. [82] carried out three-dimensional CT scanning on shotcrete to observe the agglomeration phenomenon of shotcrete under different temperatures. It was found that the pore and micro crack zone of shotcrete block at $90^{\circ} \mathrm{C}$ was much higher than that at $50^{\circ} \mathrm{C}$. Results showed that the high temperature accelerated the hydration reaction of cement and the disorderly overlapping between molecules, which led to the intensification of autogenous shrinkage of shotcrete and the poor adhesion of hydration products generated, as shown in Figure 13. In addition, the local stress in the shotcrete would produce new cracks again, which would weaken the bond performance of the internal structure of shotcrete.

Scholars have studied the effect of void structure on bond performance of shotcrete by using CT technology, which is of certain significance for analyzing the mechanical failure of shotcrete. However, there are relatively few studies on the interface between shotcrete and rock (coal) based on macro and micro analysis, and in particular, the effect of parameters of different sprayed surfaces (such as roughness, density, and chemical composition) on the bonding performance of shotcrete needs to be further studied. 


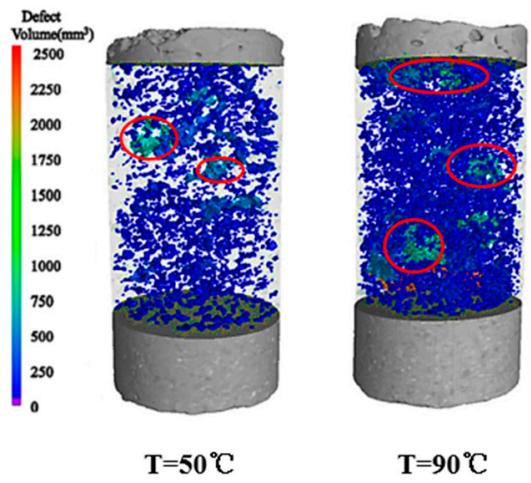

Figure 13. Porosity distribution in shotcrete based on CT image [82].

\subsection{Other Mechanical Properties of Shotcrete}

There are many failure forms of shotcrete and roadway walls in roadways $[83,84]$. The shear failure model of shotcrete and rock wall under a standard and high-temperature environment is shown in Figure 14. The internal structure of shotcrete was seriously damaged under high temperature, and the damaged particles presented an irregular state. However, the structure of shotcrete was stable after shear failure in a standard environment. Some scholars have studied the performance of shotcrete under shear failure and other forms. For example, Tang et al. [85] studied the influencing factors of shear strength at the cementation surface between shotcrete and granite under conditions of high and variable temperatures. It was concluded that normal stress has the greatest influence on the shear strength, followed by temperature and humidity, and the surface roughness of granite had the least influence. Moreover, the shear strength increased first, and then decreased with the curing temperature.
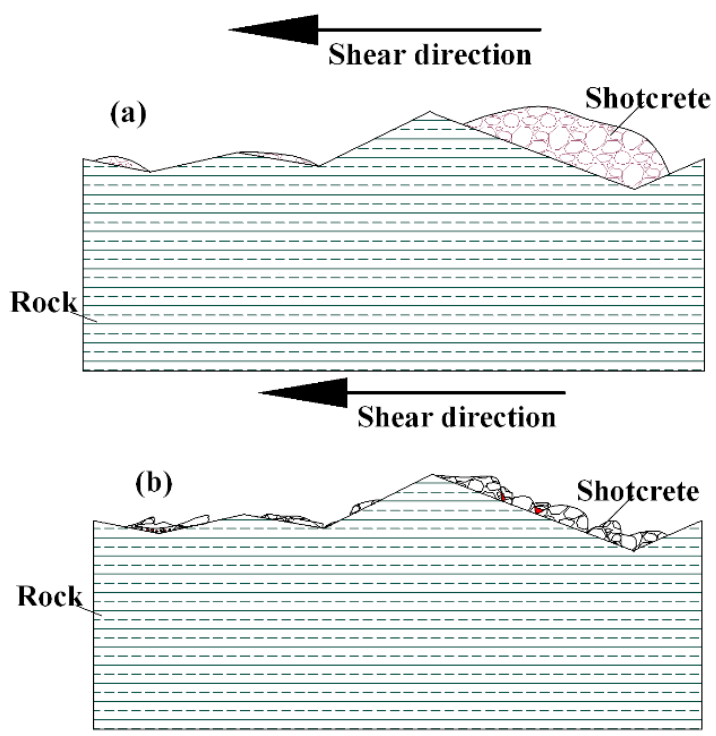

Figure 14. Shear failure model: (a) standard environment and (b) high temperature environment.

Tong et al. [86] studied the influence of different normal stresses on the interfacial shear strength of shotcrete under high-temperature conditions, and found that the shear strength first increased and then decreased with the increase of temperature, and increased with the increase of normal stress. Furthermore, the maximum shear strengths corresponding to temperature was $60{ }^{\circ} \mathrm{C}$ and $80^{\circ} \mathrm{C}$ when the relative humidity (RH) were $55 \%$ and $95 \%$. Consequently, the results showed that the higher the relative humidity was, the higher the peak shear strength and the peak cohesion were, as shown in Figure 15. Mohamed et al. [87] 
studied the limit stress of saturated shotcrete and dry shotcrete under high temperature. It was found that the thermal effect of shotcrete in a saturated state failed due to the gap pressure generated by free water evaporation during the heating stage, which destroyed the shotcrete matrix and led to serious brittle failure of shotcrete.

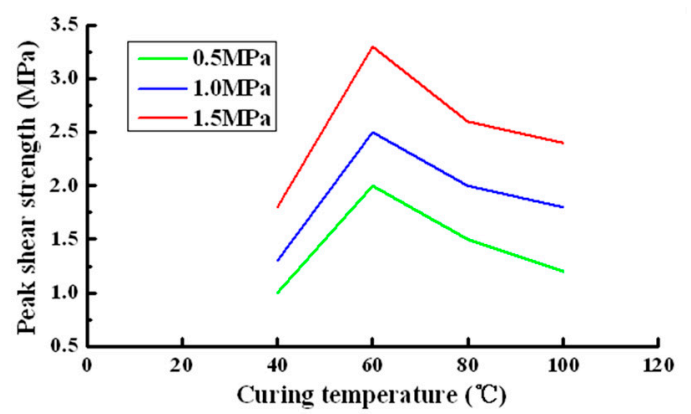

(a)

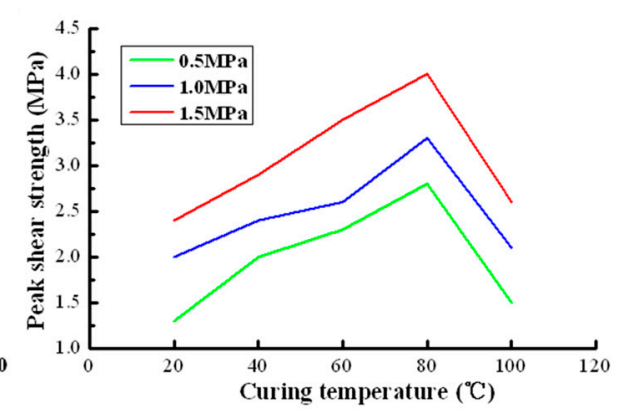

(b)

Figure 15. Variation trend of peak shear stress of C30 concrete with temperature: (a) $55 \% \mathrm{RH}$ and (b) $95 \% \mathrm{RH}[86]$.

Pan et al. [88] studied the residual strength of shotcrete under natural cooling and immersion cooling in an ultra-high temperature environment, as shown in Figure 16. The residual strength of shotcrete was higher when the temperature was lower. However, when the temperature continued to rise, the variation law of residual strength was basically the same under the two curing methods. This shows that the cement hydrate decomposes in the shotcrete under ultra-high temperature, and the bond between aggregate and cement stone becomes worse; the temperature inside and outside of the shotcrete was uneven due to water cooling under high temperature, which led to a shrinkage of the internal structure of the shotcrete. It was further explained that the performance change of shotcrete had nothing to do with the curing method when the temperature exceeded $800^{\circ} \mathrm{C}$.

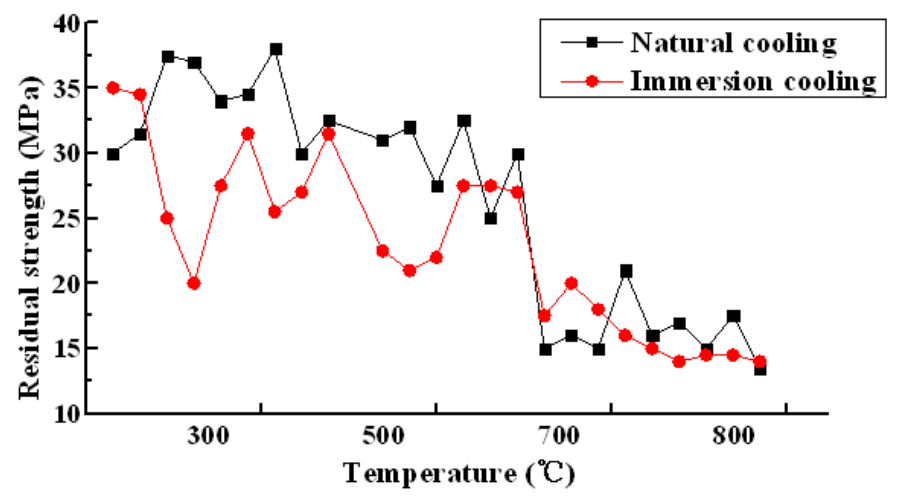

Figure 16. Residual strength of concrete under different cooling modes in a high-temperature environment [88].

There are many studies on the mechanical properties of shotcrete under high temperature, and a large number of research results have been obtained to explain the macro phenomenon from the micro point of view. However, most studies only focus on the single mechanical properties of shotcrete. The overall studies on comprehensive properties are relatively few, and the correlation between various mechanical properties needs to be further discussed. It is suggested that when studying various mechanical properties of shotcrete at high temperature, detailed micro research can be conducted separately to focus on the macro changes of various mechanical properties. This may be a relatively clear research method, rather than performing a microstructure study every time a mechanical property is studied. 


\section{Methods to Improve the Performance of Shotcrete under High Temperature \\ 4.1. Cooling Technology and Method}

At present, refrigeration technology at home and abroad mainly includes air conditioning technology, air cooling technology, ice cooling technology, and thermoelectric glycol technology [89-91], as shown in Figure 17. However, the cost of traditional technology is high, which is undesirable for a construction environment; therefore, it is necessary to solve the problem of high temperature heat damage from the perspective of new technology and new methods. For example, Jin et al. [92] studied the impermeability of concrete under high temperature with a spray-cooling method. It was found that spray-cooling could improve the ambient temperature, but the damage to the surface of the shotcrete resulted in weakening of the mechanical properties of the shotcrete. Luo et al. [93] introduced a solution using dehumidification and cooling technology, in which $\mathrm{NaCl}$ solution and $\mathrm{CaCl}_{2}$ solution are selected, and the air is cooled by the differential pressure between solution and air. Some scholars have also studied liquid $\mathrm{CO}_{2}$ cooling refrigeration technology for ventilation, and found that the air flow temperature in the air duct gradually decreased [94], and the cooling effect was very good. Reducing the high temperature in a construction environment and increasing the air humidity in the construction site can be done by physical or chemical means. A humid environment is conducive to the recovery of high-temperaturedamaged concrete strength [95]. In addition, because of the huge geothermal productivity in a high-temperature environment, geothermal refrigeration technology could also be used to improve the construction environment. Table 2 summarizes some refrigeration technologies and compares their advantages and disadvantages.

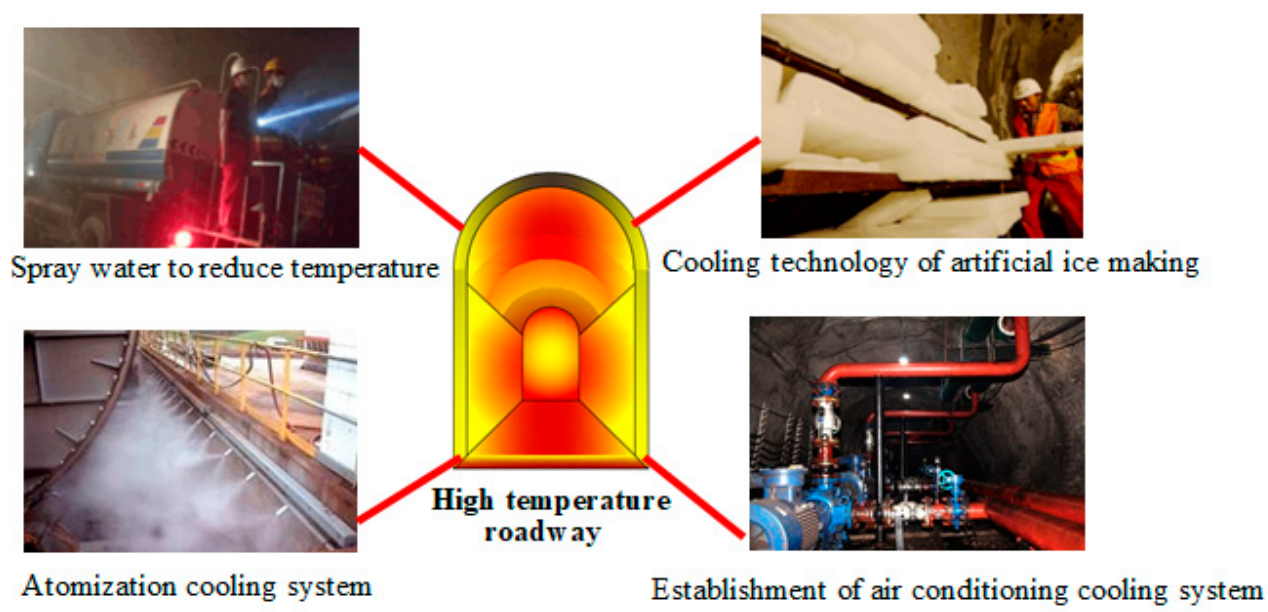

Figure 17. Refrigeration technology in high temperature construction environments.

\subsection{Experimental Study on Performance Optimization of Shotcrete}

From the safety point of view, in construction in a deep environment, we should not only ensure the stability of the roadway structure, but also improve the site construction environment. Therefore, some scholars have carried out optimization research on shotcrete. He et al. [96] studied thermal insulation shotcrete, and found that the heat insulation mechanism was to increase the temperature difference between the rock wall and construction roadway by using lightweight aggregate with osteoporosis and high porosity as the raw material. Moreover, the test showed that the shotcrete had a certain cooling effect on the construction roadway. Mohd and Zhou et al. $[97,98]$ found that shotcrete still had strong mechanical properties under ultra-high temperature by adding fly ash and metakaolin into shotcrete. Yang et al. [99] found that $67 \%$ of the residual strength could be maintained at $1000{ }^{\circ} \mathrm{C}$ when steel fiber was added into high-performance shotcrete, which could effectively inhibit the high-temperature cracking of shotcrete. 
Table 2. Comparison of advantages and disadvantages of refrigeration technology.

\begin{tabular}{|c|c|c|c|}
\hline Refrigeratio & Technology & Advantage & Disadvantage \\
\hline \multirow{4}{*}{$\begin{array}{l}\text { Air conditioning refrigeration } \\
\text { technology }\end{array}$} & Air cooling technology & $\begin{array}{l}\text { Using air as a refrigeration } \\
\text { medium, the system produced } \\
\text { no pollution in the } \\
\text { environment, and the system } \\
\text { structure was simple }\end{array}$ & $\begin{array}{l}\text { Large refrigeration equipment, } \\
\text { inconvenient to move and } \\
\text { install, poor refrigeration } \\
\text { capacity, and high } \\
\text { refrigeration cost }\end{array}$ \\
\hline & $\begin{array}{l}\text { Water refrigeration } \\
\text { technology }\end{array}$ & $\begin{array}{c}\text { The refrigeration range was } \\
\text { wide, and the cooling effect } \\
\text { was obvious }\end{array}$ & $\begin{array}{l}\text { In the process of cooling, there } \\
\text { will be a temperature jump }\end{array}$ \\
\hline & $\begin{array}{c}\text { Geothermal refrigeration } \\
\text { technology }\end{array}$ & $\begin{array}{l}\text { Making full use of waste heat } \\
\text { energy, environmental } \\
\text { protection and energy saving, } \\
\text { low operating cost }\end{array}$ & $\begin{array}{l}\text { The refrigeration range was } \\
\text { limited, so it was necessary to } \\
\text { establish multiple } \\
\text { refrigeration systems }\end{array}$ \\
\hline & Ice refrigeration technology & $\begin{array}{l}\text { High cold storage capacity } \\
\text { and high heat exchange } \\
\text { efficiency }\end{array}$ & $\begin{array}{l}\text { The conveying process was } \\
\text { easily blocked, and the } \\
\text { melting speed was low }\end{array}$ \\
\hline \multirow{3}{*}{$\begin{array}{l}\text { Non-mechanical cooling } \\
\text { technology }\end{array}$} & Spray-cooling technology & $\begin{array}{l}\text { It had the advantages of fast } \\
\text { cooling rate, low cost, and } \\
\text { good dust removal effect }\end{array}$ & $\begin{array}{l}\text { It was suitable for a tunneling } \\
\text { working face with small } \\
\text { working range, few operators, } \\
\text { small cooling capacity, and } \\
\text { serious heat damage }\end{array}$ \\
\hline & $\begin{array}{c}\text { Liquid } \mathrm{CO}_{2} \text { refrigeration } \\
\text { technology }\end{array}$ & $\begin{array}{l}\text { The conveying distance was } \\
\text { more than } 1000 \mathrm{~m} \text {, the cooling } \\
\text { effect was good, and the } \\
\text { cooling system was flexible }\end{array}$ & $\begin{array}{l}\text { When the air volume of the } \\
\text { working face is large, the } \\
\text { cooling effect will be affected }\end{array}$ \\
\hline & $\begin{array}{l}\text { Solution dehumidification } \\
\text { and cooling }\end{array}$ & $\begin{array}{c}\text { It had high dehumidification } \\
\text { efficiency, controllable } \\
\text { dehumidification capacity, } \\
\text { and low operation cost. It } \\
\text { could remove dust, bacteria, } \\
\text { and other harmful substances } \\
\text { in the air }\end{array}$ & $\begin{array}{c}\text { The initial investment cost of } \\
\text { the solution dehumidification } \\
\text { unit was high }\end{array}$ \\
\hline
\end{tabular}

However, some researchers also found that the mechanical properties of thermal insulation shotcrete mixed with vitrified microbubbles had decreased, which was explained by the formation of a large number of porous structures when vitrified beads were added into shotcrete (Figure 18). In addition, there were also scholars who added inorganic materials such as expanded perlite and silica fume into shotcrete to study its thermal insulation performance; the inorganic materials are shown in Figure 19. For example, Liu et al. [100] studied thermal insulation shotcrete by replacing sand with expanded perlite, and found that dry-spraying technology had a better thermal insulation effect. Pang et al. [101] developed a new type of shotcrete thermal insulation material by adding ceramsite, vitrified microsphere, and fly ash into shotcrete. According to the test, the thermal conductivity was between 0.1837 and $0.2533 \mathrm{w} /(\mathrm{m} \cdot \mathrm{K})$, which had certain heat insulation performance and could improve the high-temperature environment. Some scholars have put forward the idea of spraying polystyrene foam for shotcrete maintenance, reducing the temperature difference between the inside and outside of shotcrete, so as to prevent shotcrete cracks [102]. Lei et al. [103] studied the performance change of shotcrete under cement temperatures. The mechanical properties of shotcrete could be improved, and the early setting time could be shortened, by heating the cement at a certain temperature before the shotcrete was prepared. Jiang et al. [104] added plant fiber into shotcrete and found that the thermal conductivity of shotcrete decreased by $20.61 \%$ compared with that of ordinary shotcrete, and the fiber inhibited the generation of microcracks to a certain extent [105]. 


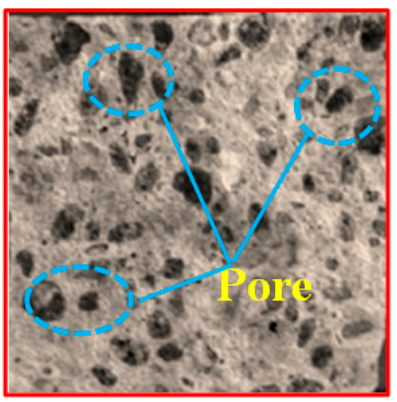

Figure 18. Cross section of thermal insulation concrete material [106].

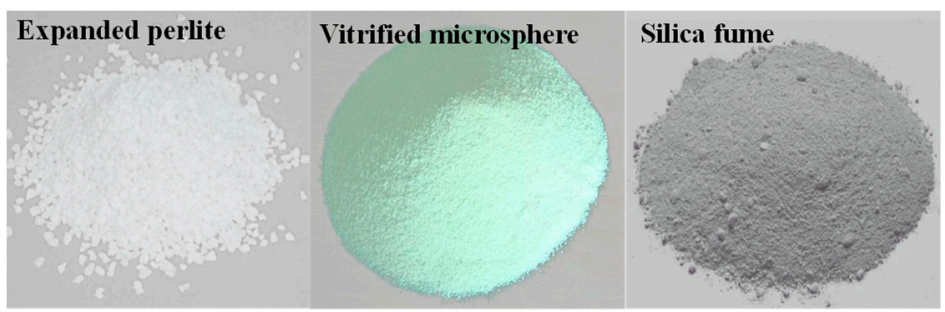

Figure 19. Inorganic materials for performance optimization of shotcrete.

Cui et al. $[107,108]$ studied the performance changes of shotcrete mixed with hook-end steel fiber (SF-HE), wave-shaped steel fiber (SF-W), and basalt fiber (BF) at $100{ }^{\circ} \mathrm{C}$, and found that the total porosity and harmful porosity of shotcrete decreased significantly after adding fiber, and the optimization effect of steel fiber on pore structure was better than that of basalt fiber. However, the porosity of shotcrete increased after the steel fiber and silica fume were mixed, which indicated that the pozzolanic activity of silica fume fails under high temperature, as shown in Figure 20. Chu et al. [109] found that the toughness of foam-fiber-reinforced shotcrete decreased, and the thermal conductivity decreased. This was because foam filled in the void of shotcrete and directly cut off the heat transfer path. Patrick et al. [110] studied the structural performance of shotcrete and concluded that the shotcrete containing alkaline accelerator had low thermal diffusivity and better thermal insulation performance. Some scholars found that the degree of C-S-H gel polymerization and chain length increased at the cemented surface when the shotcrete was mixed with silica fume. A large number of $\mathrm{CH}$ crystals generated C-S-H gel, which filled in the interface pores, which enhanced the interfacial strength $[111,112]$. This could be expressed as $\mathrm{Ca}(\mathrm{OH})_{2}+\mathrm{SiO}_{2}+\mathrm{H}_{2} \mathrm{O} \rightarrow \mathrm{C}-\mathrm{S}-\mathrm{H}$. Benarchid et al. [113] analyzed the vulcanization properties of waste rock and concluded that it had good safety. Francesco et al. [114] proposed that the performance of shotcrete could be optimized by changing the density of the material to reduce the pore pressure and the gravitational potential energy of shotcrete.

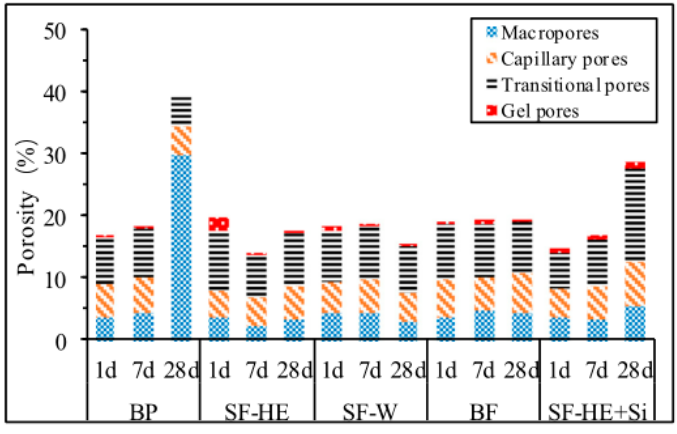

Figure 20. Porosity of different pores under different conditions [108]. BP: non-fiber material; SF-HE: $1 \%$ hook-end steel fiber; SF-W: $1 \%$ corrugated steel fiber; BF: $0.1 \%$ basalt fiber; SF-HE+Si: $1 \%$ steel fiber and 5\% silica fume. 


\section{Challenges}

At present, despite the plentiful results obtained in the field of high-temperature shotcrete research, most of the research is still in the field of tunnel engineering, and there are few studies in other underground engineering fields (such as mine engineering). Moreover, the environments of mine engineering and tunnel engineering are not the same. The mining depth of mine engineering is far greater than that of tunnel engineering. The mining environment is more severe, and the high-temperature environment is more complicated. Therefore, the research on sprayed concrete in the field of underground engineering still faces great challenges, as shown in Table 3.

Table 3. Challenges of shotcrete performance under high temperature.

\begin{tabular}{|c|c|c|}
\hline Challenges & Current Technologies & Future Challenges \\
\hline $\begin{array}{l}\text { High temperature detection technology } \\
\text { research }\end{array}$ & $\begin{array}{l}\text { Thermocouple temperature } \\
\text { measurement, infrared temperature } \\
\text { measurement, and other technologies. } \\
\text { However, the temperature can change in } \\
\text { the hot and humid environment of the } \\
\text { roadway, and a complete test system has } \\
\text { not been formed. }\end{array}$ & $\begin{array}{l}\text { Develop a new temperature } \\
\text { measurement method, establish a } \\
\text { temperature measurement system, } \\
\text { predict and forecast the high temperature } \\
\text { area of the roadway, ensure that the } \\
\text { construction environment is in a balanced } \\
\text { state, and reinforce the area where the } \\
\text { roadway sprayed concrete may be } \\
\text { damaged in advance. }\end{array}$ \\
\hline $\begin{array}{l}\text { Experimental device for performance of } \\
\text { shotcrete }\end{array}$ & $\begin{array}{l}\text { Shotcrete is made by pouring or spraying. } \\
\text { Then, constant temperature and a } \\
\text { humidity curing box or high-temperature } \\
\text { drying box are used to simulate } \\
\text { high-temperature environment curing. } \\
\text { There will be a gap in the simulation of } \\
\text { the high-temperature environment, } \\
\text { which will affect the experimental results. }\end{array}$ & $\begin{array}{l}\text { Research and development of shotcreting } \\
\text { equipment and performance testing } \\
\text { system in high temperature. Accurately } \\
\text { simulate high-temperature environment } \\
\text { to improve the authenticity of research } \\
\text { results. Provide reliable results for } \\
\text { improving the development of } \\
\text { infrastructure under high temperature. } \\
\text { Study the performance change trend of }\end{array}$ \\
\hline Shotcrete spray layer structure & $\begin{array}{l}\text { The existing research is based on the } \\
\text { study of the adhesion of shotcrete under } \\
\text { the action of temperature, but it has not } \\
\text { involved research on the shotcrete } \\
\text { spraying layer in the process of roadway } \\
\text { reinforcement under high temperature. }\end{array}$ & $\begin{array}{l}\text { high-temperature roadway shotcrete with } \\
\text { the thickness of shotcrete layer. Get the } \\
\text { optimal spray layer thickness under high } \\
\text { temperature. Study the adhesion } \\
\text { between spray layers. Research and } \\
\text { develop high-efficiency, environmentally } \\
\text { friendly, and low-cost adhesives }\end{array}$ \\
\hline $\begin{array}{l}\text { Performance of shotcrete in special } \\
\text { environments }\end{array}$ & $\begin{array}{l}\text { Existing research is based on the } \\
\text { permeability of shotcrete, and there is } \\
\text { basically no relevant literature on the } \\
\text { high-temperature conditions of the } \\
\text { construction roadway in a } \\
\text { high-water-spray environment. }\end{array}$ & $\begin{array}{l}\text { Study the mechanical properties of } \\
\text { shotcrete in high-temperature acid and } \\
\text { alkaline environments. Investigate the } \\
\text { non-linear relationship between the } \\
\text { compatibility of the sprayed concrete and } \\
\text { the cemented surface of the } \\
\text { high-water-spray area and the interface's } \\
\text { mechanical properties. }\end{array}$ \\
\hline Microscopic properties of shotcrete & $\begin{array}{l}\text { The existing research has explained the } \\
\text { deterioration performance of shotcrete at } \\
\text { high temperature from the micro level, } \\
\text { but it is still not perfect. There is no } \\
\text { detailed study on the crack development } \\
\text { process and deterioration mechanism of } \\
\text { concrete in a high temperature } \\
\text { environment. }\end{array}$ & $\begin{array}{l}\text { Study the microscopic changes of } \\
\text { shotcrete under high temperature. } \\
\text { Establish a damage model of shotcrete } \\
\text { under high temperature. Study the } \\
\text { impact properties of shotcrete layers } \\
\text { under high temperature. Establish a } \\
\text { damage prediction model for shotcrete } \\
\text { layer structure under high temperature, } \\
\text { using acoustic emission technology to } \\
\text { predict the development trend of } \\
\text { shotcrete deterioration in advance. }\end{array}$ \\
\hline
\end{tabular}


Table 3. Cont.

\begin{tabular}{ccc}
\hline Challenges & Current Technologies & Future Challenges \\
\hline Optimization of shotcrete & $\begin{array}{c}\text { Existing research is mainly based on } \\
\text { studies of thermal insulation sprayed } \\
\text { concrete, which is mainly improved from } \\
\text { the material ratio by adding inorganic } \\
\text { materials. Although it has a certain } \\
\text { thermal insulation effect, its thermal } \\
\text { insulation performance is insignificant } \\
\text { for the ultra-high temperature } \\
\text { construction environment. }\end{array}$ & $\begin{array}{c}\text { Study the modification of shotcrete. } \\
\text { Choose low-quality, } \\
\text { reduce the potential energy of concrete. } \\
\text { Preliminary research on the high } \\
\text { temperature resistance between silica } \\
\text { aerogel and shotcrete. }\end{array}$ \\
\hline
\end{tabular}

\section{Conclusions}

In recent years, a large number of scholars have carried out various studies on the mechanical properties and micro characteristics of shotcrete at high temperature. This paper systematically discusses the evolution mode and process of concrete performance under high temperature:

(1) This paper first reviewed the causes of the formation of high temperature environments, and pointed out that formation temperature was a kind of heat conduction mode. The leading role of rock thermal conductivity on temperature transmission was determined by introducing the multi-dimensional morphological formula in the process of heat conduction.

(2) The mechanical properties and micromechanical properties of shotcrete under high temperature were reviewed. Results concluded that the mechanical properties (including compressive strength, tensile strength, bond strength, shear strength) of shotcrete were affected by the critical temperature: before the critical temperature, the mechanical properties of shotcrete showed an increasing trend with the increase of temperature; after the critical temperature, the mechanical properties of shotcrete appeared to show the phenomenon of shrinkage. Through microscopic analysis, multiple studies have shown that when the temperature exceeds the critical temperature, the internal molecules of the shotcrete move violently and the molecules overlap in a disorderly way, the hydration reaction of shotcrete cement is terminated prematurely, and the brittle de-formation is enhanced, which leads to the weakening of shotcrete strength.

(3) The cooling technology and performance optimization of shotcrete at high temperature are summarized. It is concluded that taking cooling measures for a hightemperature construction environment will increase the recoverability of concrete after deterioration and reduce the deterioration degree of shotcrete. In terms of optimizing the performance of shotcrete, adding inorganic materials, such as vitrified microbeads, foam fibers, expanded perlite, and silica fume, will improve the heat insulation and heat resistance of shotcrete.

(4) The research status of shotcrete technology under high temperature was analyzed from the aspects of equipment, materials, and technology. It was found that the current temperature measurement system, high-temperature simulation equipment, and material ratio had limitations. At the same time, the challenges that high-temperature shotcrete faces in terms of the process structure, performance optimization, and its application in special engineering fields were summarized.

Funding: This study was funded by the National Key Research and Development Plan of the 13th Five-Year Period (Grant No. 2017YFC0805203); National Natural Science Foundation of China (Grant No. 51974177, 51934004); and Natural Science Foundation of Shandong (Grant No. ZR201801280006, ZR2019QEE007, ZR2019MEE115).

Institutional Review Board Statement: Not applicable. 
Informed Consent Statement: Not applicable.

Data Availability Statement: Not applicable.

Conflicts of Interest: The authors declare that they have no known competing financial interest or personal relationship that could have appeared to influence the work reported in this paper.

\section{References}

1. Xiamen Academy of Building Sciences Group Co., Ltd. Technical Specification for Application of Sprayed Concrete JGJ/T 372; China Construction Industry Press: Beijing, China, 2016.

2. Burns, B.D. Characterization of Wet-Mix Shotcrete for Small Line Pumping; Laval University: Québec, QC, Canada, 2008.

3. Brooks, J.W. Shotcrete and its application. In Shotcreting Proceedings; South African Institute of Mining and Metallurgy School: Johannesburg, South Africa, 1998.

4. Chen, L.; Li, P.; Liu, G.; Cheng, W.; Liu, Z. Development of cement dust suppression technology during shotcrete in mine of China-A review. J. Loss Prev. Process. Ind. 2018, 55, 232-242. [CrossRef]

5. Liu, G.; Chen, L.; Cheng, W.; Huang, Y. Research on pump primers for friction reduction of wet-mix shotcrete based on pre-creating lubricating layer. Adv. Mater. Sci. Eng. 2017, 2017, 1-12.

6. Zhu, K.; Zhou, Y.; Wang, P.; Liu, J.; Shi, C. Study on monitoring technique and distribution regularity of geothermal field in deep mining. Nonferrous Met. 2016, 68, 90-94.

7. Chen, X. Prediction and analysis of ground temperature in deep mining of metal mine. Sci. Technol. Inf. 2017, 15, 94-111.

8. Zhang, C.; Zhao, L.; Wu, Z. Depth characteristics of Curie surface in the Eastern seas of China. J. Shandong Univ. Sci. Technol. 2019, $38,10-17$.

9. Wang, X.; Li, X.; Kong, F.M. Metamorphism and tectonic evolution of the sedimentary-matrix mélange in the central Yarlung Zangbo Suture Zone, Southern Tibet. J. Shandong Univ. Sci. Technol. 2020, 39, 16-27.

10. Yao, H.; Xu, C.; Wu, H.; Zheng, Z.; Sun, X.; Wang, H.; Chai, J.; Li, Y. Study on geothermal parameters of mid-deep and deep mines in Inner Mongolia and Shaanxi mining area. China Coal 2017, 43, 91-96.

11. Wang, C. Analysis of thermal damage factors in deep mine. Zhongzhou Coal. 2013, 40, 42-105.

12. Guo, Z. Current situation and technical problems of deep mining in China's coal mines. Coal 2017, 26, 58.

13. He, M.; Guo, P. Deep rock mass thermodynamic effect and temperature control measuresd. Chin. J. Rock Mech. Eng. 2013, 32, 2377-2393.

14. Shengai, C.; Pin, L.; Jiao, S.; Enqi, C.; Chen, G.; Bing, Z. Experimental study on mechanical and microstructural properties of cement-based paste for shotcrete use in high-temperature geothermal environment. Constr. Build. Mater. 2018, 174, 603-612.

15. Lee, C.-H.; Wang, T.-T.; Chen, H.-J. Experimental study of shotcrete and concrete strength development in a hot spring environment. Tunn. Undergr. Space Technol. 2013, 38, 390-397. [CrossRef]

16. Yang, H. Performance Research and Structural Behavior Analysis of Shotcrete in Thermal Damage Tunnel; Southwest Jiaotong University: Chengdu, China, 2013.

17. Wang, J.; Niu, D.; Wang, Y.; He, H.; Liang, X. Chloride diffusion of shotcrete lining structure subjected to nitric acid, salt-frost degradation, and bending stress in marine environment. Cem. Concr. Compos. 2019, 104, 103396. [CrossRef]

18. Wang, J.; Niu, D.; Ding, S.; Mi, Z.; Luo, D. Microstructure, permeability and mechanical properties of accelerated shotcrete at different curing age. Constr. Build. Mater. 2015, 78, 203-216. [CrossRef]

19. Cui, S.A.; Li, J.W.; Ye, Y.Z.; Yang, H.Y. Bond Strength of shotcrete with rock in dry and hot environment of high ground temperature tunnel. J. Build. Mater. 2013, 4, 663-666.

20. Dong, W.; Yang, D.; Zhou, X.; Kastiukas, G.; Zhang, B. Rimental and numerical investigations on fracture process zone of rock-concrete interface. Fatigue Fract. Eng. Mater. Struct. 2017, 40, 820-835. [CrossRef]

21. Yang, C.; Chen, J. Fully noncontact nonlinear ultrasonic characterization of thermal damage in concrete and correlation with microscopic evidence of material cracking. Cem. Concr. Res. 2019, 123, 105797. [CrossRef]

22. Lu, T.; Zhao, G.; Lin, Z. Experimental study on mechanical properties of long standing concrete after exposure to high temperature. J. Build. Struct. 2004, 25, 63-70.

23. Lu, T.; Zhao, G.; Lin, Z.; Yue, Q.R. Microscopic analysis of long standing concrete after high temperature. J. Build. Mater. 2003, 6, 135-141.

24. Kjellsen, K.O. Heat curing and post-heat curing regimes of higher-performance concrete: Inflfluence on microstructure and C-S-H composition. Cem. Concr. Res. 1996, 26, 295-307. [CrossRef]

25. Akca, A.H.; Zihnioğlu, N.Ö. High performance concrete under elevated temperatures. Constr. Build. Mater 2013, 44, 317-328. [CrossRef]

26. Zonno, G.; Aguilar, R.; Boroschek, R.; Lourenço, P.B. Analysis of the long and short-term effects of temperature and humidity on the structural properties of adobe buildings using continuous monitoring. Eng. Struct. 2019, 196, 1-21. [CrossRef]

27. Kang, F.; Li, J.; Zhao, S.; Wang, Y. Structural health monitoring of concrete dams using long-term air temperature for thermal effect simulation. Eng. Struct. 2019, 180, 642-653. [CrossRef]

28. Liu, L.; Zhang, J. Thermal insulation composite material for governance of underground thermal hazard and its application. $J$. Shandong Univ. Sci. Technol. Nat. Sci. 2017, 36, 46-53.

29. Wang, Z.; Yin, Y.; Zhao, T.; Ma, J.; Wu, W. Numerical simulation of the mechanism of the hole expansion and anchorage and support control in soft rock roadway. J. Shandong Univ. Sci. Technol. Nat. Sci. 2021, 40, 9. 
30. Xin, S.; Meng, X.; Qu, Y.; Chen, X. Mechanism analysis of heat harm in large dip angle coal mining working face. J. Shandong Univ. Sci. Technol. Nat. Sci. 2016, 35, 42-48.

31. Lin, X. Formation and distribution of ground temperature field in mines. Inn. Mong. Sci. Econ. 2011, 62-63.

32. Conti, M.; Pata, V.; Pellicer, M.; Quintanilla, R. On the analyticity of the MGT-viscoelastic plate with heat conduction. J. Differ. Equ. 2020, 269, 7862-7880. [CrossRef]

33. Zhang, Y.-L.; Li, T.; Mou, R.-T.; Wang, C.-Z.; Yuan, F.-C. Study of underground temperature prediction method for deep exploitation of mines under complicated circumstances. J. Qingdao Technol. Univ. 2015, 36, 1-6.

34. Zhou, Y.; Gu, L.; Li, L.; Wu, L. Study on thermal conductivity of rock and thermophysical properties of coal. Energy Technol. Manag. 2011, 143, 134-135.

35. Luo, J.; Qi, Y.; Zhao, Q.; Tan, L.; Xiang, W.; Rohn, J. Investigation of flow and heat transfer characteristics in fractured granite. Energies 2018, 11, 1228. [CrossRef]

36. Luo, J.; Zhu, Y.; Guo, Q.; Tan, L.; Zhuang, Y.; Liu, M.; Zhang, C.; Xiang, W.; Rohn, J. Experimental investigation of the hydraulic and heat-transfer properties of artificially fractured granite. Sci. Rep. 2017, 7, 39882. [CrossRef]

37. Zhan, F.L.; Cai, M.F. Rock heat-transfer model of high-temperature stopes and its solving process. In Proceedings of the International Young Scholars' Symposium on Rock Mechanics, Beijing, China, 28 April-2 May 2008.

38. Tan, Y.; Zhang, Q. Numerical analysis of surrounding rock deformation and failure in deep roadway under the condition of thermal-solid coupling. J. Shandong Univ. Sci. Technol. Nat. Sci. 2016, 35, $29-37$.

39. Liu, G.; Guo, X.; Cheng, W.; Chen, L.; Cui, X. Investigating the migration law of aggregates during concrete flowing in pipe. Constr. Build. Mater. 2020, 251, 119065. [CrossRef]

40. Liu, G.; Cheng, W.; Chen, L.; Pan, G.; Liu, Z. Rheological properties of fresh concrete and its application on shotcrete. Constr. Build. Mater. 2020, 243, 118180. [CrossRef]

41. Zhu, P.; Yu, S.; Liu, W.; Sun, Y. Review of the research status of high performance concrete anti-tunnel fire spalling. Concrete 2018, 24-29.

42. Li, Y.; Shi, K.; Chen, Z.; Li, Z. Study on the early crack resistance of high performance concrete under the condition of high temperature curing. Yellow River 2017, 39, 130-132.

43. Huang, G.; Zhang, R.; Zhang, R.; Hua, L.; Guo, H. Effect of high temperature on mechanical properties of early age concrete. Railw. Eng. 2019, 59, 140-142.

44. Qin, L.; Li, M.; Ding, J.-N. The effect from curing of high temperature and high humidity to durability of high strength concrete. J. Northeast. China Inst. Electr. Power Eng. 2016, 36, 18-22.

45. Li, X.-H.; Wang, J.; Duan, Y. Research on the effects of high temperature tunnel of sprayed concrete performance. J. Hebei Univ. Technol. 2014, 31, 17-20.

46. Hiremath, P.N.; Yaragal, S.C. Effect of different curing regimes and durations on early strength development of reactive powder concrete. Constr. Build. Mater. 2017, 154, 72-87. [CrossRef]

47. Jung, W.; Choi, S.J. Effect of high-temperature curing methods on the compressive strength development of concrete containing high volumes of ground granulated blast-furnace slag. Adv. Mater. Sci. Eng. 2017, 2017, 1-6. [CrossRef]

48. Mymrin, V.; Aibuldinov, E.K.; Alekseev, K.; Petukhov, V.; Avanci, M.A.; Kholodov, A.; Taskin, A.; Catai, R.E.; Iarozinski, A.N. Efficient road base material from Kazakhstan's natural loam strengthened by ground cooled ferrous slag activated by lime production waste. J. Clean. Prod. 2019, 231, 1428-1436. [CrossRef]

49. D'aloia, L.; Benboudjema, F.; Briffaut, M. Effect of fibres on early age cracking of concrete tunnel lining. Part II: Numerical simulations. Tunn. Undergr. Space Technol. 2016, 59, 215-220.

50. Pin, L.; Shengai, C.; Zihao, L.; Xuefeng, X.; Chen, G. Inflfluence of surrounding rock temperature on mechanical property and pore structure of concrete for shotcrete use in a hot-dry environment of high-temperature geothermal tunnel. Constr. Build. Mater. 2019, 207, 329-337.

51. Zhu, L.-L.; Zhao, Y. Effect of temperature on the properties of high strength sprayed concrete. Bull. Chin. Ceram. Soc. 2017, $36,2424-2429$.

52. Naus, D.J. The Effect of Elevated Temperature on Concrete Materials and Structures-A Literature Review; Oak Ridge National Laboratory: Oak Ridge, TN, USA, 2006.

53. Carpinteri, A.; Lacidogna, G.; Pugno, N. Structural damage diagnosis and life-time assessment by acoustic emission monitoring. Eng. Fract. Mech. 2007, 74, 273-289. [CrossRef]

54. Grosse, C.; Ožbolt, J.; Richter, R.; Periškić, G. Acoustic emission analysis and thermo-hygromechanical model for concrete exposed to fire. J. Acoust. Emiss. 2010, 28, 188-203.

55. Geng, J.; Sun, Q.; Zhang, W.; Lü, C. Effect of high temperature on mechanical and acoustic emission properties of calcareousaggregate concrete. Appl. Therm. Eng. 2016, 106, 1200-1208. [CrossRef]

56. Li, Z. Study on Deterioration Information and Performance Guarantee of Shotcrete in Deep Mine; Shandong University of Science and Technology: Qingdao, China, 2018.

57. Xie, Z.; Li, X. Effect of curing temperature and curing time on compressive strength of fly ash geopolymer concrete. Concrete 2014, 55-58.

58. Wang, C. Influence of High Temperature Curing on Strength and Durability of High Strength Concrete for C80 Pile; Southwest Jiaotong University: Chengdu, China, 2015.

59. Frigione, M.; Mairo, N. Concrete mixing at elevated temperature: Workability, strength and durability. Cem. Wapno Beton 2015, 2015, 115-129. 
60. Calvo, J.G.; Alonso, M.C.; Luco, L.F.; Velasco, M.R. Durability performance of sustainable self compacting concretes in precast products due to heat curing. Constr. Build. Mater. 2016, 111, 379-385. [CrossRef]

61. Qu, H. Experimental Study and Numerical Simulation Analysis of Concrete Performance After High Temperature; Jilin University: Changchun, China, 2018.

62. Deng, M.; Cheng, Y.; Weng, S.; Zhang, Y. Compressive properties and micro-structure of high ductility concrete exposed to elevated temperature. Acta Mater. Compos. Sin. 2020, 37, 985-996.

63. Hassan, A.; Aldhafairi, F.; Abd-EL-Hafez, L.M.; Abouelezz, A.E.Y. Retrofitting of different types of reinforced concrete beams after exposed to elevated temperature. Eng. Struct. 2019, 194, 420-430. [CrossRef]

64. Wang, M.; Hu, Y.; Wang, Q.; Tian, H.; Liu, D. A study on strength characteristics of concrete under variable temperature curing conditions in ultra-high geothermal tunnels. Constr. Build. Mater. 2019, 229, 116989. [CrossRef]

65. Fan, L.; Zhang, Z.; Yu, Y.; Li, P.; Cosgrove, T. Effect of elevated curing temperature on ceramsite concrete performance. Constr. Build. Mater. 2017, 153, 423-429. [CrossRef]

66. Chen, G.; Xu, P.; Mi, G.; Zhu, J. Compressive strength and cracking of composite concrete in hot-humid environments based on microscopic quantitative analysis. Constr. Build. Mater. 2019, 225, 441-451. [CrossRef]

67. Wei, J.-X.; Yu, Q.-J.; Zeng, X.-X.; Bai, R.-Y. Fractal dimension of pore structure of concrete. J. South China Univ. Technol. 2007, $2,121-124$.

68. Jianbo, Y.; Jihui, T.; Zhongmin, Z.; Xiaoming, Y.; Shenli, X. Application of shotcrete and its permeability, pore structure and mechanical properties. Qinghai Jiaotong Keji 2019, 114-117.

69. İlhami, D.; Merve, G.H.; Süleyman, G. Gamma ray and neutron shielding characteristics of polypropylene fiber-reinforced heavyweight concrete exposed to high temperatures. Constr. Build. Mater. 2020, 257, 119596.

70. Yang, W. Microstructure of ettringite formed under different curing conditions. J. Chin. Electron Microsc. Soc. 2000, 523-524.

71. Shen, J.; Xu, Q. Characteristics of pore structure change and compressive strength reduction of concrete under elevated Temperatures. Mater. Rep. 2020, 34, 2046-2051.

72. Schiller, K.K. Mechanical Properties of Non-Metalic Brittle Materials; Butter-Worth: London, UK, 1958.

73. Chen, L.; Zhou, Z.; Liu, G.; Cui, X.; Dong, Q.; Cao, H. Effects of substrate materials and liner thickness on the adhesive strength of the novel thin spray-on liner. Adv. Mech. Eng. 2020, 12, 1687814020904574. [CrossRef]

74. Liu, J.; Mei, Y.; Xia, R. A new wetting mechanism based upon triple contact line pinning. Langmuir ACS J. Surf. Colloids 2011, 27, 196-200. [CrossRef] [PubMed]

75. Ma, Q.; Duan, Y.; Su, H.; Tang, Y.; Wang, J.; Li, X.; Ma, C.H. Analysis on impacts of different rock wall temperatures on bonding strength between surrounding rock and shotcrete. Water Resour. Hydropower Eng. 2015, 46, 62-65.

76. Ou, Z. Study on Performance and Technology of Shotcrete in Thermal Environment; Southwest Jiaotong University: Chengdu, China, 2011.

77. Su, H.; Li, X.; Wang, J. Bonding strength of Shotcrete for tunnel under high ground temperature and its finite element analysis. Water Resour. Hydropower Eng. 2016, 47, 54-57.

78. Ma, F.; Su, H.; Ma, C.; Huang, S.; Li, Q. Experimental Simulation Study on the High Geothermal Temperature Surrounding Rock and Tunnel Lining Model Based on ANSYS. Yellow River 2018, 40, 113-116.

79. Su, H.; Huang, S.; Qu, C.-L. Analysis the distribution characteristics of pore structure in shotcrete affected by high temperature. Sci. Technol. Eng. 2016, 16, 225-229.

80. Fan, L.; Li, P.; Yu, Y.; Zhang, Z. Experimental study on the effect of curing temperature on shotcrete properties. Bull. Chin. Ceram. Soc. 2017, 36, 3487-3492.

81. Duan, L.; Zhang, Y.; Lai, J. Influence of ground temperature on shotcrete-to-rock adhesion in tunnels. Adv. Mater. Sci. Eng. 2019, 2019, 8709087. [CrossRef]

82. Tang, Y.; Xu, G.; Lian, J.; Su, H.; Qu, C. Effect of temperature and humidity on the adhesion strength and damage mechanism of shotcrete-surrounded rock. Constr. Build. Mater. 2016, 124, 1109-1119. [CrossRef]

83. Hassanein, A.Y.A.; Mohamed, N.; Farghaly, A.; Benmokrane, B. Effect of boundary element confinement configuration on the performance of GFRP-Reinforced concrete shear walls. Eng. Struct. 2020, 225, 111262. [CrossRef]

84. Torelli, G.; Gillie, M.; Mandal, P.; Draup, J.; Tran, V.X. A moisture-dependent thermomechanical constitutive model for concrete subjected to transient high temperatures. Eng. Struct. 2020, 210, 110170. [CrossRef]

85. Tang, X.; Wang, J.; Dong, C.; Wang, Y. Shear Strength of cementation plane between shotcrete and granite under high and variable temperature. J. China Railw. Soc. 2017, 39, 131-136.

86. Jianjun, T.; Murat, K.; Mingnian, W.; Congyu, D.; Xinghua, T. Shear strength characteristics of shotcrete-rock interface for a tunnel driven in high rock temperature environment. Geomech. Geophys. Geo-Energy Geo-Resour. 2016, 2, 331-341.

87. Saidi, M.; Vu, X.H.; Ferrier, E. Experimental and analytical analysis of the effect of water content on the thermomechanical behaviour of glass textile reinforced concrete at elevated temperatures. Cem. Concr. Compos. 2020, 112, 103690. [CrossRef]

88. Pan, P.; Tao, Z.; Lu, Y.; Chen, L.; Zeng, Y.; Li, D.; Pan, Z. Experimental study on high temperature mechanical properties of machine-made sand concrete based on residual strength. Constr. Technol. 2020, 49, 67-69.

89. He, M.; Guo, P.; Chen, X.; Meng, L.; Zhu, Y. Research on characteristics of high-temperature and control of heat-harm of sanhejian coal mine. Chin. J. Rock Mech. Eng. 2010, 29, 2593-2597.

90. Yu, C. Research on Local Environment Cooling Technology of High Temperature Mine; Shandong University of Science and Technology: Qingdao, China, 2017. 
91. Twort, C.T.; Lowndes, I.S.; Pickering, S.J. An application of thermal energy analysis to the development of mine cooling systems. J. Mech. Eng. Sci. 2002, 216, 845-857. [CrossRef]

92. Jin, Q.; Li, H.; Chen, W. Experimental research on spray cooling on the permeability of concrete at different temperatures. China South. Agric. Mach. 2019, 50, 226-227.

93. Luo, Y.; Wang, H.; Zhang, Y. Research and application of cooling technology in roadway driving in the mine at high temperature. Nonferrous Met. Sci. Eng. 2020, 11, 85-91.

94. Xu, L. Experimental Study on Cooling of Liquid $\mathrm{CO}_{2}$ in High Temperature Tunneling Face; Liaoning University of Engineering and Technology: Shenyang, China, 2017.

95. Liu, L.X.; Lv, L.; Liu, Z.; Wang, H.Y. Investigation on the Mechanical Behavior of Concrete at and after Elevated Temperature. Build. Sci. 2005, 3, 16-20.

96. He, Z. Research on Test and Application of Thermal Insulation Shotcrete in High Temperature Roadway; Anhui University of Science and Technology: Huainan, China, 2018.

97. Yunus, N.Z.M.; Ayub, A.; Wahid, M.A.; Satar, M.K.I.M.; Abudllah, R.A.; Yaacob, H.; Hassan, S.A.; Hezmi, M.A. Strength behaviour of kaolin treated by demolished concrete materials. In Proceedings of the IOP Conference Series: Earth and Environmental Science, Johor, Malaysia, 27-28 August 2019; Volume 220.

98. Zhou, J.; Li, H.; Zheng, W.; Ma, X.; Zhang, J.; Yang, Y. Effect of fly ash and metakaolin mixture on mechanical properties of high strength concrete at different temperature. Bull. Chin. Ceram. Soc. 2019, 38, 3952-3958.

99. Yang, T.; Liu, Z.; Yang, Y.; Wu, C. Experimental investigation on behavior of ultra-high performance concrete after high temperature. J. Civ. Environ. Eng. 2020, 42, 115-126.

100. Liu, T.; Liu, L.; Ji, S. Performance analysis of thermal insulation expanded perlite shotcrete in deep mine. Ind. Constr. 2018, 739-741.

101. Pang, J.-Y.; Yao, W.-J.; Yao, W.-J. Experimental research on performance of new type of thermal insulation concrete material in high-temperature tunnel. China Concr. Cem. Prod. 2016, 1, 5-9.

102. Wang, R. Crack control of super-long concrete structure under temperature stress. Henan Build. Mater. 2020, 111-112.

103. Lei, W. Research on the influence of cement temperature on concrete performance. J. Commer. Concr. 2019, 40-42, 56.

104. Jiang, P.; Fang, J.; Pang, J.; Huang, J. Analysis of mechanical properties and microscopic properties of plant fiber sprayed concrete [J/OL]. J. Yangtze River Sci. Res. Inst. 2020, 137-141, 149.

105. Lianjun, C.; Xixin, Z.; Guoming, L. Analysis of dynamic mechanical properties of sprayed fiber-reinforced concrete based on the energy conversion principle. Constr. Build. Mater. 2020, 254, 119167.

106. Yao, W.-J. Research and Application of Insulated Concrete Shotcrete Support Technology for Deep High Ground Temperature Rock Roadway; Anhui University of Science and Technology: Huainan, China, 2019.

107. Cui, S.; Liu, P.; Cui, E.; Su, J.; Huang, B. Experimental study on mechanical property and pore structure of concrete for shotcrete use in a hot-dry environment of high geothermal tunnels. Constr. Build. Mater. 2018, 173, 124-135. [CrossRef]

108. Cui, S.; Xu, D.; Liu, P.; Ye, Y. Exploratory study on improving bond strength of shotcrete in hot and dry environments of high geothermal tunnels. KSCE J. Civ. Eng. 2016, 21, 2245. [CrossRef]

109. Chu, Z.; Zhou, G.; Bi, S. Meso-characterization of the effective thermal conductivity of selected typical geomaterials in an underground coal mine. Energy Explor. Exploit. 2018, 36, 488-508. [CrossRef]

110. Bamonte, P.; Gambarova, P.G.; Nafarieh, A. High-temperature behavior of structural and non-structural shotcretes. Cem. Concr. Compos. 2016, 73, 42-53. [CrossRef]

111. Mu, W. Quantitative Characterization of Interfacial Microstructure and Its Relationship with Mechanical Properties of Concrete; Changjiang River Scientific Research Institute: Wuhan, China, 2017.

112. Gorlenko, N.P.; Sarkisov, Y.S.; Demyanenko, O.V.; Kopanitsa, N.O.; Sorokina, E.A.; Gorynin, G.L.; Nichinskiy, A.N. Fine-grained concrete fibre-reinforced by secondary mineral wool raw material. J. Phys. 2018, 1118, 012059. [CrossRef]

113. Benarchid, Y.; Taha, Y.; Argane, R.; Tagnit-Hamou, A.; Benzaazoua, M. Concrete containing low-sulphide waste rocks as fine and coarse aggregates: Preliminary assessment of materials. J. Clean. Prod. 2019, 221, 419-429. [CrossRef]

114. Monte, F.L.; Felicetti, R.; Miah, M.J. The influence of pore pressure on fracture behaviour of Normal-Strength and HighPerformance Concretes at high temperature. Cem. Concr. Compos. 2019, 104, 103388. [CrossRef] 